\title{
Farmland Ownership and Its Impact on the Debt Servicing Capacity Among U.S. Married-Couple Farm Households
}

\author{
Hisham S. El-Osta ${ }^{1}$ \\ ${ }^{1}$ Agricultural Economist with the Economic Research Service, United States Department of Agriculture. The views \\ expressed are those of the author and do not necessarily represent the policies or views of ERS or USDA. \\ Correspondence: Hisham S. El-Osta, Economic Research Service, United States Department of Agriculture, Washington \\ DC, USA.
}

Received: July 29, 2016

doi:10.11114/aef.v3i4.1865
Accepted: August 16, $2016 \quad$ Available online: September 7, 2016

URL: http://dx.doi.org/10.11114/aef.v3i4.1865

\begin{abstract}
Farmland ownership among U.S. farm businesses constitutes the major type of farm tenure arrangements as only about 8 percent of all farms are operated under full rental agreements. This research seeks to discern the impact of full-ownership of farmland, which accounts for nearly two-thirds of how farms are operated, on the debt servicing capacity of married U.S. farm couples. Findings based on data from the 2004-2013 Agricultural Resource Management Survey along with regression procedures indicated a strong and statistically significant positive impact of farmland ownership on the ability of these farm households to service their debt. Increases in unemployment rates and the occurrence of the 2008 economic recession were among the factors that were found with a strong adverse impact on debt servicing capacity.
\end{abstract}

Keywords: Debt repayment capacity, unemployment rate, metro area, Internet use, endogenous treatment effect model, quantile regression

\section{JEL Classification: E23, D14, L86, Q12, Q15}

\section{Introduction}

The economic well-being of farm households has been the central focus of policy makers since the implementation of price and income supports in the 1930s. A significant contributor to an economically well-positioned farm household is the ability to generate the cash needed that would allow, in addition to reinvestment and saving, for expenditures to be met on such items as family living expenses, taxes, and the repayment of debt. Many economists have examined whether farmers in various types of farm production and classes of farm sales would be able to repay their farm debts, particularly at times of falling prices, and have designed strategies that are aimed at assisting farmers in managing their debt servicing capacity (see Miller, Boehlje, \& Dobbins, 2000; Harris et al., 2009). ${ }^{1}$ The specific uses of farm household income to manage household living expenditures have been highlighted by Mishra et al. (2002). For example, households in 1999 headed by operators 35 or younger, considering family needs (e.g., education, clothing, personal items, etc.), had the highest average living expenditures $(\$ 35,652)$. In contrast, households headed by those 65 or older, considering their ability to align their minimal consumption needs with income as they approach retirement, had the lowest average expenditures (\$10,079). A study by Aguiar \& Hurst (2013) had asserted a humped-shaped life-cycle of living expenditure for non-farm households.

Farm real estate (i.e., all agricultural land and buildings) in the U.S. constitutes more than 80 percent of the total value of farm assets (Nickerson et al., 2012; Borchers \& Kuethe, 2012). About two-thirds of all farms tend to operate

\footnotetext{
${ }^{1}$ Debt servicing capacity is defined as the maximum amount of debt that the farm household could afford to borrow. It is based on the income generating capacity of the farm business while allowing for the household's living expenditures and taxes, and while making assumptions about interest rates and the amount of debt that lenders would be willing to extend against this income [see Harris et al., 2009; Gloy, 2015]. When this measure is evaluated against the debts held by the farm household in order to ascertain whether they are sustainable, another pertinent measure is obtained; the debt repayment capacity utilization (DRCU). Harris et al. (2009) report that debt repayment capacity utilization (DRCU) of farm operators has dropped since the 1980s, with the level dropping from 27 percent in 2000 to 22 percent in 2007. For the sake of establishing a benchmark, DRCU in 1997 was at 56 percent, nearly the highest level since the U.S. farm financial crisis of the 1980s (see Stam et al., 1998; Barnett, 2000).
} 
farmland that are fully-owned (Hoppe, 2014). Since the operators of these farms are more likely to generate nearly all of their income from working off-farm (Mishra et al., 2002;), adverse changes in the farm economy and of macroeconomic factors with their attendant downward impact on farmland values might consequently affect the financial well-being of a major segment of the farming population. This is particularly relevant to older farmers as those farmers over age 55 control more than half of the farmland (Mishra, Wilson, \& Williams 2009).

The main objective is to discern the potential impact of farm ownership on the debt servicing capacity (DSC) of U.S. married-couple farm operator households using national data from the 2004-2013 Agricultural Resource Management Survey (ARMS). The relevance of using this time frame in the analysis of this proxy of farmer's credit worthiness is inclusion of the major economic recession, as demonstrated by the 6-percent reduction in non-farm employment and the doubling of the national unemployment rate between 2007 and 2009 (see Hertz et al. 2014). While farmers with full-ownership of their land--who comprise the majority of farms-- tend to have the least in average farm debt, in comparison to part-time owners or full-tenants, any major devaluation of U.S. farmland as was witnessed in the 1980s could place significant downward pressure on the equity position of the farming sector. The chart in the upper-left corner of Figure 1 shows the sharp rise in the unemployment rate during the economic recession. The remaining charts of the figure demonstrate the spatial variation in the extent of unemployment rates by county, with the highest rates during the period of economic-slowdown demonstrably falling in many of the Midwestern counties, and in the Southeastern and Western counties. In 2005, and based on data from the ARMS, 35 percent of married farm couples, which constitute the targeted population in the study, had both the farm operators and their spouses working concurrently off the farm. During the economic recession in 2008, this off-farm labor participation rate had dropped to 31 percent, with a slight rise in the rate to 32 percent in 2013 after the economy had fully recovered.

U.S. Unemployment Rate: 2004-2013

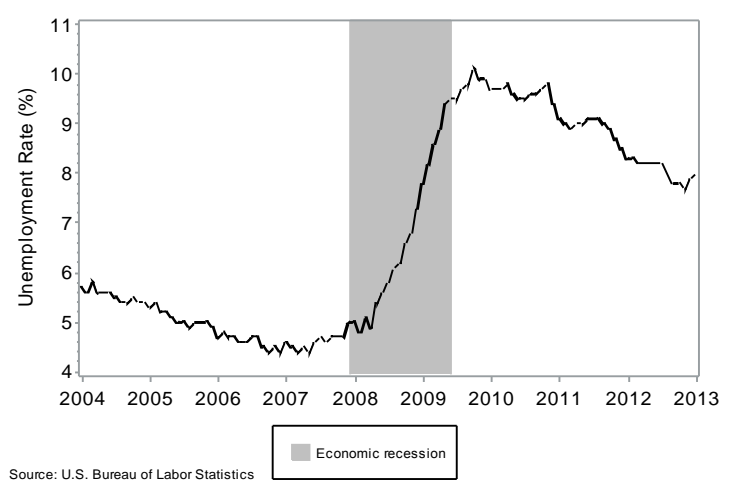

2008 (economic recession)

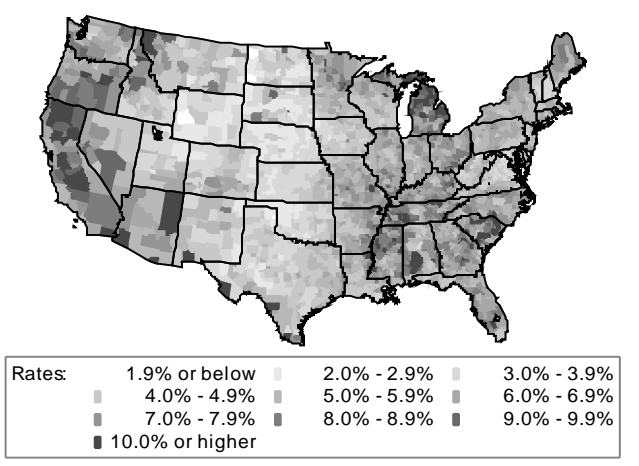

2004

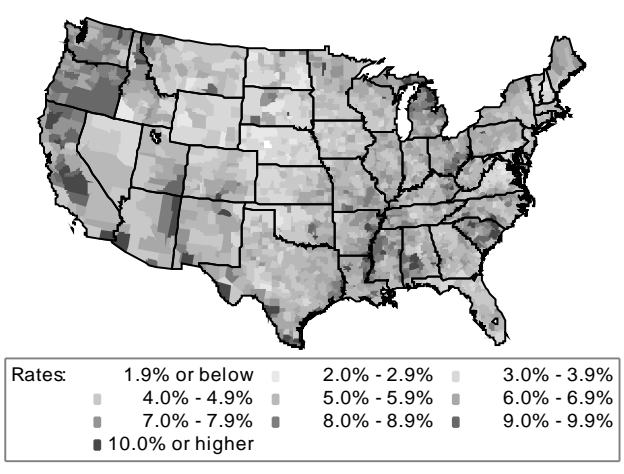

$\underline{2013}$

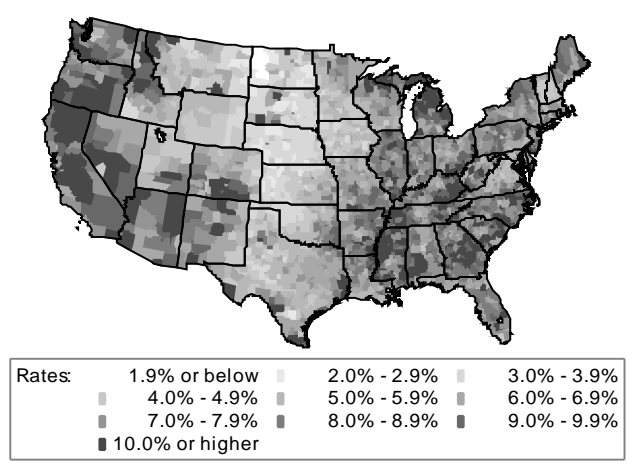

Figure 1. Unemployment Rates in the U.S. and in the Lower 48 States by County: 2004-2013

\section{Previous Research}

Since early in the1990s, research analysts with the Economic Research Service of the U.S. Department of Agriculture have produced financial indicators describing farmers' ability to service their farm debt; indicators that were important for banks in assessing farmers' credit worthiness before providing loan approvals (see Ryan \& Morehart 1992; Ryan 
1995). The role of income and how it correlates with higher debt servicing capacity was explored by, among others, Featherstone, Roessler, \& Barry (2006); and Briggeman, Towe, \& Morehart (2009).

Despite the important role that farm ownership plays in the financial position of farm households, only a limited number of studies have addressed such a relationship. A study by D'Antoni, Mishra, \& Chintawar (2009) looked at this issue in the context of young and beginning farmers and found that tenant farmers in this category of farm operators were 1.4 percent more likely to be financially stressed than full owners. ${ }^{2}$ The specific positive impact of off-farm income on the credit payment capacity of farmers with its attendant impact in making the loan portfolios of farm lenders more stable was explored by Stam et al. (2003). A study by Briggeman (2011) noted that since many farm households rely on off-farm income as their main source of income, instabilities in the local nonfarm economy as captured by the variation in the unemployment rates in the local communities are likely to impact their debt repayment capacity. The health of both farm and non-farm economies in terms of their impact on farm profitability are two factors with varied implications on farmers' ability to finance, and consequently to service, their farm debt. Research by Mishra \& Goodwin (1997) show a positive association between the variability in farm income and the incidence of off-farm work by farm operators. Covey et al assert (2004) that farm debt repayment would not appear to pose a problem for the nearly two-thirds of farm operator households that are likely to report of having no farm debt outstanding. However, this may not be the case in terms of the potential difficulty for about one-third of these farm households who own no farm debt but carry existing loan balances for non-farm purposes to service this debt; particularly during unexpected downturns in the general and/or farm economy.

Gloy (2015) notes that farm debt tends to be concentrated among larger farms; for example, those nearly ten percent of farm businesses with sales of over $\$ 1$ million and who account for fifty percent of all farm debt. Harris et al. (2009) point out that large farms, and those farms with capital intensive production practices tend to rely more on debt financing in their farming operations than a smaller and a less-capital intensive typical farm. Kropp and Katchova (2011) find farm programs' direct payments to have the potential to impact the liquidity and repayment capacity of those farm businesses that receive payments, particularly for established and experienced farmers. The study further suggests that direct payments have the potential to alter the access to credit in addition to the likelihood of altering farms' current production decisions.

\section{Data}

The primary data source for the analysis is a set of pooled cross sections from the 2004-2013 ARMS. ${ }^{3}$ The ARMS, which has a complex stratified, multi-frame design, is a national survey conducted annually by the Economic Research Service and the National Agricultural Statistics Service (for more detail, see ERS 2015). The target population of the survey is operators of farm businesses representing agricultural production in the 48 contiguous states. A farm in the U.S. is defined as an establishment that sold or normally would have sold at least $\$ 1,000$ of agricultural products during the year. Each observation in the ARMS of sample size $n$ represents a number of similar farms, the particular number being the survey weight, or $w_{i}(i=1, \ldots, n)$. To demonstrate, the size of the initial 2013 ARMS sample was 15,799, which when properly expanded using the ARMS' survey weights represents a population of farm operator households totaling 2,044,493. ${ }^{4}$ After including only farm operator households with married couples, as in Tokle \& Huffman (1991), since they are the primary decision making units regarding consumption and production in farm households, the resulting sample size and expanded number of farm households based on the 2013 ARMS were 13,096 and 1,655,092, respectively.

\section{Empirical Estimation}

The distribution of the variable $y$ depicting the debt servicing capacity of farm households in the selected sample, as shown in the top panel of Figure 2, is left-censored at near zero, and is positively skewed. This implies a violation of the basic normality assumption of the distribution of the error terms, which is needed in standard regression methods of inference and prediction (see Box \& Cox, 1964; Kmenta, 1986). Such violation is further illustrated by the wide gap that exists between the $y$ weighted mean and median estimates $(\$ 304,619$ and $\$ 149,426$, respectively) and by the

\footnotetext{
${ }^{2}$ Young and beginning farmers are defined as those farm operators who are under the age of 35 and with farming experience of less than 10 years.

${ }^{3}$ Data from auxiliary sources were also used. For example, information on county characteristics were obtained from the Regional Economic Information System files (Bureau of Economic Analysis), the 2004-2013 Local Area Unemployment Statistics (Bureau of Labor Statistics) files, and the 2000 Census of Population, STF-3 file.

4 These are the sample sizes that remained after primarily excluding from the analysis those observations where the farm of the household is organized as 'Non-family Corporation or Cooperative', or where none of the net income generated by the farm business is received by the household itself. The remaining observations are those of family farms organized as self-proprietorships, partnerships, and family C- or S-Corporations.
} 
excessively large measured skewness and kurtosis coefficients (21.40 and 973.19 , respectively). ${ }^{5}$ A consequence of this violation in the context of linear regression in general is that the resulting estimates of model's parameters are inconsistent (Burbidge, Magee, and Robb, 1988). To remedy this violation, a logarithmic transformation of $y$ is implemented in the specification of the linear regression models used in the analysis (see Gould \& Saupe 1989, and Briggeman 2011), where $Y=\log (y)$. The lower panel of Figure 2 illustrates that such a transformation generated something closer to symmetry around the mean of $Y$ (see Deaton 1989; Altonji and Doraszelski 2001). ${ }^{6}$
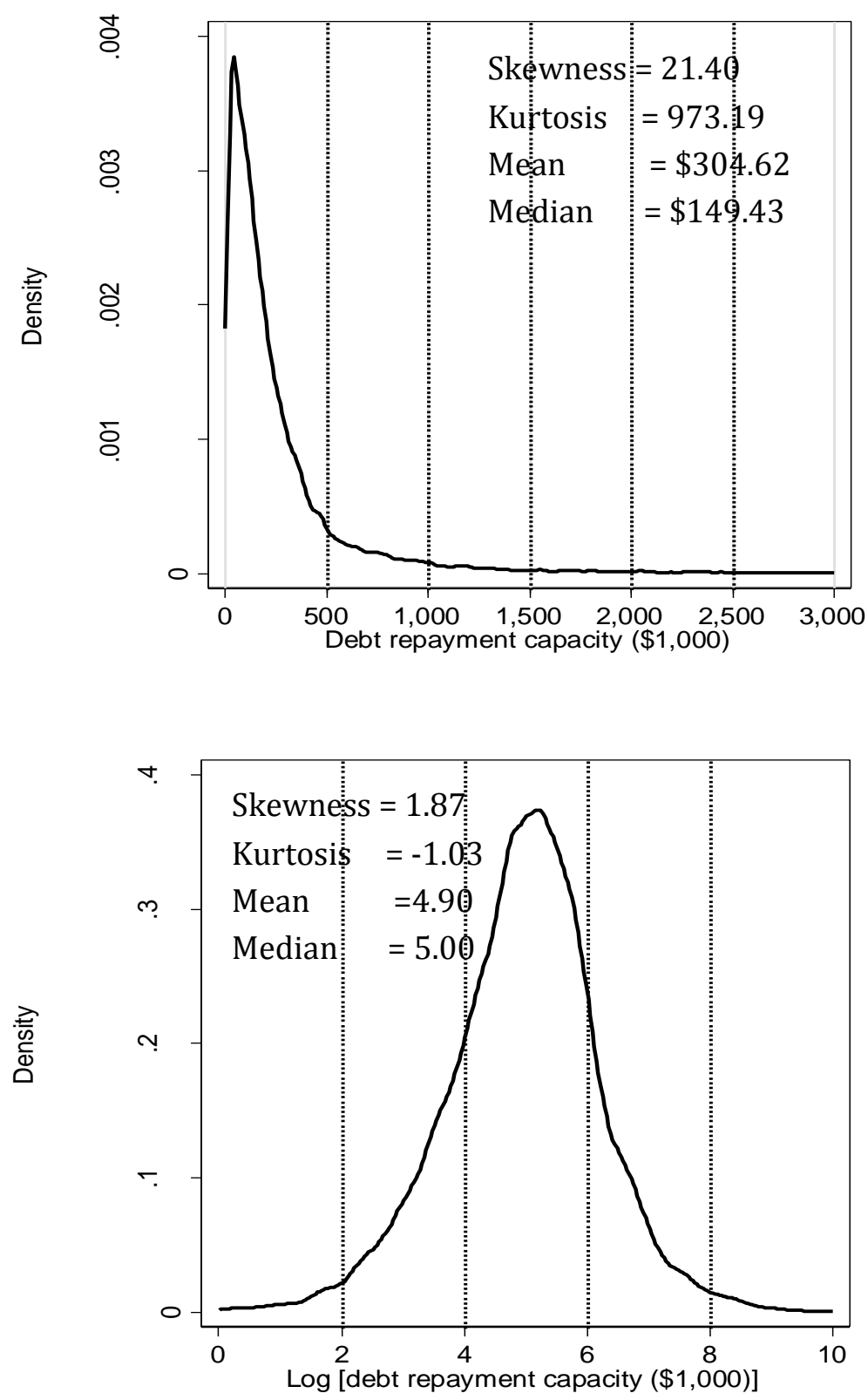

Figure 2. Kernel Density Estimates of Debt Servicing Capacity Using Level and Log-Level Values: 2004-2013

\footnotetext{
5 The normality assumption of the distribution of $Y$, if found valid, would have implied that the mean and median estimates are closer to each other and that the measured skewness and kurtosis coefficients are very close to zero. The null hypothesis that $Y$ is normally distributed was also rejected based on the Jarque-Bera test of normality (i.e., computed joint $\chi^{2}$ statistic $=166,014 ; P$-value $<0.000)$.

${ }^{6}$ Other transformation methods that can be used to correct for non-normality in a univariate distribution are the Box-Cox and the inverse hyperbolic sine transformation approaches (see Box and Cox 1964; and Burbidge, Magee, and Robb 1988, respectively).
} 


\subsection{Linear Regression Model}

Estimating the impact of full-ownership of farmland $\left(X_{i l}\right)$ by the $i$ th $(i=1, \ldots, n)$ married-couple farm household on its debt servicing capacity, in log form (i.e., outcome variable $Y_{i}$ ), is depicted by the following endogenous treatment effect regression model [LRETE], also known as an endogenous binary-variable model (see StataCorp, 2013):

$$
\begin{gathered}
Y_{i}=\beta_{0}+\sum_{j=1}^{k} \beta_{j} X_{i j}+\delta X_{i l}+\varepsilon_{i}=X_{i} \beta+\delta X_{i l}+\varepsilon_{i} \\
X_{i l}=\left\{\begin{array}{l}
1, \text { if } W_{i} \gamma+v_{i}>0 \\
0 \text { o the r w i s e }
\end{array}\right.
\end{gathered}
$$

where $X_{i}$ is a vector of explanatory variables describing the characteristics of the farm operator, of the farm household, and of the farm business, $W_{i}$ is a vector of explanatory variables used to model full-ownership of the farmland by the farm household as captured by the binary variable $X_{i l}$ (i.e., treatment assignment), $\delta$ is a parameter that captures the average treatment effect (i.e., the average impact on $Y$ due to farm households' full-ownership of farmland), and $\varepsilon_{i}$ and $v_{i}$ are bivariate error terms with variances $\sigma^{2}$ and 1 , respectively, and with mean zero, and with correlation coefficient $\rho$ and covariance $\lambda$, where $\lambda=\sigma \rho$.

Use of the LRETE model here is justified since the 0-1indicator variable $X_{i l}$ that denotes whether the farmland is fully owned is possibly endogenous. Endogeneity here may arise as unobserved factors (e.g., preference for adopting potentially expensive yet productivity-enhancing and/or labor saving technology; unobserved institutional characteristics of the local government as it relates to real estate taxes, among other things, where the farm household is located; etc.) captured in the error terms in (1) and (2) are likely to be correlated with their corresponding observed determinants, a consequence of which is that the estimated parameters in (1) will be biased and inconsistent. In this paper, the LRETE model is estimated by means of maximum likelihood. The log-likelihood function for the $i$ th observation (see Maddala 1983, p. 122; Greene 2000, p. 180; StataCorp, 2013, p. 22) is described as in the following:

$$
\ln L_{i}= \begin{cases}\ln \Phi\left\{\frac{W_{j} \gamma+\left(Y_{i}-X_{i} \beta-\delta\right) \rho / \sigma}{\sqrt{1-\rho^{2}}}\right\}-\frac{1}{2}\left(\frac{Y_{i}-X_{i} \beta-\delta}{\sigma}\right)^{2}-\ln (\sqrt{2 \pi} \sigma) & X_{i q}=1 \\ \ln \Phi\left\{\frac{-W_{j} \gamma-\left(Y_{i}-X_{i} \beta\right) \rho / \sigma}{\sqrt{1-\rho^{2}}}\right\}-\frac{1}{2}\left(\frac{Y_{i}-X_{i} \beta}{\sigma}\right)^{2}-\ln (\sqrt{2 \pi} \sigma) & X_{i q}=0,\end{cases}
$$

where $\Phi($.$) is the cumulative distribution function of the standard normal distribution. Resulting likelihood ratio-test$ concerning the independence of equations (1) and (2) will allow for the assertion of whether or not the $\varepsilon_{i}$ and $v_{i}$ are correlated, or in other words, whether or not $X_{i l}$ is endogenous.

\subsection{Quantile Regression Model}

This regression technique, as originally proposed by Koenker \& Bassett (1978), allows for the modelling of the conditional quantiles of the joint distribution of $Y$ and $X$, unlike in linear regression which models $\mathrm{E}(Y \mid X)$. The linear quantile regression procedure with a probability density function $f$ specifies the $\tau$ th conditional quantile relationship, denoted by Quant (.), between $Y$, and the set of explanatory variable $X$ as (see Buckinsky 1994 and 1995; Chen, Lin, \& Chang 2009):

$$
\operatorname{Quant}_{\tau}\left(Y_{i} \mid X_{i}\right)=\beta_{0}+\sum_{j=1}^{k} \beta_{j} X_{i j}+\delta X_{i l}=X_{i}^{\prime} \beta_{\tau}+u_{i, \tau} \quad \text { wher } \tau=\int_{-\infty}^{X_{i}^{\prime} \beta_{\tau}} f_{Y}(s \mid X) \mathrm{d} s .
$$

Letting $\omega_{\tau}$ denote a weighting function used to center the data subject to the $\tau$ th quantile, the estimator $\hat{\beta}_{\tau}$ of the $\tau$ th sample quantile $(0<\tau<1)$ of $Y$ is obtained by solving the following minimization problem which is done using linear programming: 


$$
\min _{\beta} \underset{n}{1} \sum_{i=1}^{n} \omega_{\tau}\left|Y_{i}-X_{i}^{\prime} \beta\right|=\min _{\beta} \underset{n}{1}\left[\sum_{i \in\left\{i: Y_{i} \geq X_{i}^{\prime} \beta\right\}}^{n} \tau\left|Y_{i}-X_{i}^{\prime} \beta\right|+\sum_{i \in\left\{i: Y_{i}<X_{i}^{\prime} \beta\right\}}^{n}(1-\tau)\left|Y_{i}-X_{i}^{\prime} \beta\right|\right] .
$$

As noted by Buchinsky (1998), when $\tau$ is increased from 0 to 1 , this allows for the conditional distribution of $Y$ conditional on $X$ in (5) to be obtained in its entirety. In this paper, the estimates $\hat{\beta}_{\tau}$ were obtained for $\tau=0.10,0.25$, 0.50 (i.e., the median), 0.75 , and 0.90 . Standard errors of the estimates of $\hat{\beta}_{\tau}$ were computed, as in the case of $\hat{\beta}$ in (1), based on resampling methods. ${ }^{7}$

To test and to account for the possibility that the 0-1indicator variable $X_{i l}$ in (4) that captures the full-ownership of the farmland by the farm household is endogenous, a two-step control function estimation procedure as proposed by Vella (1992), and as generalized by Lee (2007) in the context of quantile regression, was implemented. The first step estimates the likelihood of full-ownership of farmland by the farm household as described in (2) using a probit regression model, which results in the estimated parameters $\hat{\gamma}$, the standard cumulative distribution function $\Phi($.$) , and$ the probability density function of the standard normal $\varphi($.$) , and the generalized residuals as in (see Maddala 1983,$ pp. 120-122; Gourieroux 1987; Hunter 2006;):

$$
\hat{\lambda}_{i}=\left\{\left[X_{i l}-\Phi\left(\hat{\gamma}^{\prime} W_{i}\right)\right] \varphi\left(\hat{\gamma}^{\prime} W_{i}\right)\right\}\left\{\left(1-\Phi\left(\hat{\gamma}^{\prime} W_{i}\right)\right) \Phi\left(\hat{\gamma}^{\prime} W_{i}\right)\right\}^{-1}
$$

The next step involves estimating the debt carrying capacity, in log form $(Y)$, using the regression models in (4) with both $X_{i l}$ and $\hat{u}$ included. A $t$-test of the hypothesis that the coefficient of $\hat{u}$ equals zero is a test of the exogeneity of $t$ (see Smith \& Blundell, 1986; Vella 1993), and failure to include $\hat{u}$ in (4) based on a rejection of this hypothesis will yield inconsistent and biased parameter estimates. This two-stage predictor substitution method to attend to endogeneity concerns thus allows for regression estimates in the debt carrying capacity regression model to be consistent (see Lee 2007; Terza, Basu, \& Rathouz, 2008).

\section{Results}

Table 1 provides summary statistics of the variables used in the multivariate linear and quantile regression models. The average debt servicing capacity $(D S C)$ of married-couple farm households over the decade long pooled cross sections of ARMS samples was at about $\$ 305,000 .^{8}$ The great majority of these households tended to work off the farm, and to have farms that were fully owned, that were operated as sole proprietorships, and with annual farm sales of $\$ 50,000$ or less.

\footnotetext{
${ }^{7}$ When data with a complex survey design is used in full rather than as a subset as in this paper, the Jackknife $(J K)$ variance estimation method provides a proper approach to measure the variances of estimated parameters of regression models (for further detail in the context of the ARMS, see, Kott 1997; Dubman 2000). In lieu of the $J K$ method, and to remedy the computational limitation caused by the partial use of the ARMS data, this paper uses the bootstrapping technique (see Efron and Tibshirani 1994; Adkins and Hill 2004).

${ }^{8}$ Debt servicing capacity for the farm operator household is the amount of income generated from farm and nonfarm sources to cover debt repayment and capital replacement. DSC here is computed based on the recommendations of the Farm Financial Standards Council (2011) as in the following steps:

Maximum loan payment $=$ income for debt coverage $=$ total household income - withdrawals for family living - income taxes + depreciation expense + total capital interest expense + capital lease payments

Debt servicing capacity $=$ Maximum loan payment $\mathrm{x}\left(1-(1+r)^{-n}\right) / r$,

where $\left(1-(1+r)^{-n} / r\right.$ is the present value of an annuity of $\$ 1$ at $r$, which is percent market nominal interest rate and $n$ is the repayment term (see Harris 2009; Briggeman 2011), and here, it is set at 7 years.

In this paper, $r$, is the average effective interest rate on non-real estate loans made to farmers in the respective survey year (see Board of Governors of the Federal Reserve System Agricultural Finance Databook at:

https://www.kansascityfed.org/ /media/files/publicat/research/indicatorsdata/agfinance/tables.pdf). For example, in 2005, this rate was at $6.7 \%$ and in 2013, it was at $4.1 \%$. In terms of income taxes, only Federal income taxes were estimated and these levels were imputed reflecting each respective year's tax bracket as set by the Internal Revenue Service (United States Department of the Treasury) for married couples filing jointly with two dependent children. The importance of the State income tax varies greatly. Three-fourth of the states levy an individual income tax with top marginal tax rates ranging from 3 to 13 percent. In most instances, the State income tax is a relatively small share of the total tax burden for farmers.
} 
Table 1. Summary Statistics of Variables Used in The Weighted Regression Models: 2004-2013 ${ }^{1}$

\begin{tabular}{|c|c|c|}
\hline Definitions & Mean & $\begin{array}{c}\text { Standard } \\
\text { Error }\end{array}$ \\
\hline \multicolumn{3}{|l|}{ Dependent variable $^{2}$} \\
\hline Log (total farm household debt servicing capacity, $\$ 1,000$ ) & $4.90^{*}$ & 0.010 \\
\hline Farm tenue: full-ownership $(1 ; 0)$ & 0.64 & -- \\
\hline \multicolumn{3}{|l|}{ Explanatory variables } \\
\hline \multicolumn{3}{|l|}{ Operator, household, farm, and county characteristics } \\
\hline Age of farm operator: 35 year old or younger $(1 ; 0)$ & 0.04 & -- \\
\hline Education of farm operator: college (i.e., BA, BS, or graduate school) $(1 ; 0)$ & 0.25 & -- \\
\hline Farm annual sales: less than $\$ 50,000(1 ; 0)$ & 0.75 & -- \\
\hline Farm annual sales: $\$ 50,000-\$ 250,000(1 ; 0)$ & 0.14 & -- \\
\hline Internet usage by farm $(1 ; 0)$ & 0.45 & -- \\
\hline Farm has crop insurance coverage $(1 ; 0)$ & 0.16 & -- \\
\hline $\log$ (operating expense ratio) ${ }^{3}$ & 0.96 & 0.007 \\
\hline $\log$ (intensity of farm payments) ${ }^{4}$ & 0.07 & 0.001 \\
\hline Farm type: cash grains (including other field crops) $(1 ; 0)$ & 0.11 & -- \\
\hline Farm type: dairy $(=1 ; 0$ otherwise $)$ & 0.03 & -- \\
\hline Farm location (county classification): Metro $(1 ; 0)$ & 0.40 & -- \\
\hline County annual precipitation (inches) & 37.08 & 0.105 \\
\hline County unemployment rate $(\%)$ & 6.95 & 0.042 \\
\hline Years dummy variables (2004-2014) & Yes & -- \\
\hline Farm tenure: full-ownership $(1 ; 0)$ & 0.64 & -- \\
\hline \multicolumn{3}{|l|}{ Exclusion restriction variables } \\
\hline Operator occupation: farming $(1 ; 0)$ & 0.45 & -- \\
\hline Farm organization: sole proprietorship $(1 ; 0)$ & 0.92 & -- \\
\hline Sample size & 73,131 & \\
\hline Average number of farm operator households & $1,630,538$ & \\
\hline
\end{tabular}

${ }^{1}$ Primary data source: 2004-2013 Agricultural Resource Management Survey (Version 1, Phase III).

${ }^{2}$ Total farm household debt servicing capacity $(\$ 1,000$; in $2013 \$)=304.62$.

${ }^{3}$ Computed as: $\log [($ total cash expenses) / (gross cash farm income $)+1],{ }^{4}$ Computed as: Log [(total farm payments) / (gross cash farm income) +1$]$.

*Means for continuous variables are statistically significant at 5\% (standard deviations are computed using 1,000 bootstrap replicate samples).

The farm households in the reference group of the regression models, in addition to married farm couples, are those whose farm operators are older than 35 years in age and with no college education, and whose farms are of commercial size (i.e., annual sales greater than $\$ 250,000$ ), and that operate their businesses without the use of the Internet, without having crop insurance coverage, and that specialize in farm types other than those characterized as cash crops or dairy farming. The time frame for those farm households in the reference group is the 2004-2007 time period.

Table 2 presents the weighted maximum likelihood regression estimates of factors affecting farm debt servicing capacity based on linear regression endogenous binary regression model as described in equations (1) and (2). The likelihood ratio test's result in the footnote of Table 2, with $\chi_{d f=1}^{2}=134.27(p=0.00)$, shows that the null hypothesis of no correlation between $\varepsilon_{i}$ and $v_{i}$ in equations (1) and (2), respectively, can be rejected, thereby affirming the suitability of using the LRETE model to account for the endogeneity of the variable depicting the farm household's full ownership of farmland. The fact that $\rho$ the estimated correlation between the treatment-assignment errors and the outcome errors is -0.5445 and statistically significant indicates that unobservable factors that increase the likelihood of full-ownership of farmland tend to simultaneously occur with unobservable factors that decrease the capacity of farm households to repay their farm household debt. 
Table 2. Weighted Maximum Likelihood Regression Estimates of Factors Affecting the Log of Debt Servicing Capacity (DSC) of Farm Households, 2004-2013 ${ }^{1}$

\begin{tabular}{|c|c|c|c|c|}
\hline \multirow[t]{2}{*}{ Variable } & \multicolumn{2}{|c|}{$\log (\mathrm{DSC})$} & \multicolumn{2}{|c|}{ Full owner $(0,1)$} \\
\hline & $\hat{\beta}$ & $\begin{array}{c}\text { Bootstrap Std. } \\
\text { Error }\end{array}$ & $\hat{\beta}$ & $\begin{array}{l}\text { Bootstrap } \\
\text { Std. Error }\end{array}$ \\
\hline Intercept & $5.5688^{* * *}$ & 0.0596 & $-0.22283^{* * *}$ & 0.0576 \\
\hline Age: $<=35$ years & 0.0045 & 0.0592 & $-0.39375^{* * *}$ & 0.0545 \\
\hline College eduction & $0.4556^{* * *}$ & 0.0242 & $0.09902^{* * *}$ & 0.0242 \\
\hline Sales: less than $\$ 50,000$ & $-1.8944^{* * *}$ & 0.0466 & $0.8939^{* * *}$ & 0.0289 \\
\hline Sales: $\$ 50,000-\$ 250,000$ & $-1.1364^{* * *}$ & 0.0287 & $0.2922^{* * *}$ & 0.0267 \\
\hline Internet usage by farm business & $0.3054^{* * *}$ & 0.0215 & $-0.0921^{* * *}$ & 0.0223 \\
\hline Crop insurance coverage & $0.3619^{* * *}$ & 0.0336 & $-0.5266^{* * * *}$ & 0.0276 \\
\hline Log (operating expense ratio) & $-0.1003^{* * *}$ & 0.0143 & 0.0084 & 0.0148 \\
\hline Log (intensity of farm payments) & $-0.3352^{* * *}$ & 0.0696 & $0.9623^{* * *}$ & 0.0679 \\
\hline Cash grains & $0.1816^{* * *}$ & 0.0335 & $-0.3668^{* * *}$ & 0.0326 \\
\hline Dairy & $0.1534^{* * *}$ & 0.0485 & $-0.3089^{* * *}$ & 0.0517 \\
\hline Metro & -0.0001 & 0.0222 & $0.0913^{* * *}$ & 0.0220 \\
\hline Precipitation & -0.0004 & 0.0007 & $-0.0026^{* * *}$ & 0.0007 \\
\hline Unemployment rate & $-0.0168^{* * *}$ & 0.0040 & $0.0119^{* *}$ & 0.0040 \\
\hline Year: 2008 (financial crisis) & $-0.0929^{* *}$ & 0.0429 & $0.1122^{* *}$ & 0.0437 \\
\hline Year: 2009 & -0.0456 & 0.0417 & $0.0870^{* *}$ & 0.0398 \\
\hline Year: 2010 & -0.0086 & 0.0346 & $0.1185^{* *}$ & 0.0396 \\
\hline Year: 2011 & 0.0553 & 0.0346 & $0.1035^{* *}$ & 0.0359 \\
\hline Year: 2012 & $0.0633^{* *}$ & 0.0313 & $0.1828^{* * *}$ & 0.0322 \\
\hline Year: 2013 & $0.0680^{* *}$ & 0.0338 & $0.1010^{* *}$ & 0.0348 \\
\hline Full owner & $1.2626^{* * *}$ & 0.0924 & -- & -- \\
\hline Occupation: farmer & -- & -- & $-0.2625^{* * *}$ & 0.0220 \\
\hline Sole Proprietor & -- & -- & 0.0006 & 0.0357 \\
\hline$\rho$ & $-0.5445^{* * *}$ & 0.0368 & & \\
\hline$\sigma$ & $1.3350^{* * *}$ & 0.0227 & & \\
\hline$\lambda=\rho^{*} \sigma$ & $-0.7271^{* * *}$ & 0.0595 & & \\
\hline Wald $\chi_{1}^{2}$ & 134.27 & b. $\left.>\chi^{2}=0\right)$ & & \\
\hline
\end{tabular}


Note: Wald test of independence of equations $(\rho=0): \chi_{1}^{2}=134.27 \quad$ Prob. $>\quad \chi_{1}^{2}=0.00$.

${ }^{1}$ The LRETE model was estimated using etregress command (Standard errors are based on 1,000 replicate samples).

Findings with regard to the determinants of full-ownership of farmland by the farm household, which are the explanatory variables in equation (2) of the LRETE model, indicate a higher probability of such tenure type when the farm operator has a college education. A similar finding of a higher likelihood of full-ownership is found to be associated with farms that receive most of their cash farm income from government payments and with those in the small or intermediate farm-size range. The finding with regard to the impact of small farm size on the higher likelihood of farm ownership is in line with the reporting by Cochrane (1993) and Gilbert \& Harris (1984) that smaller farms are more likely to be full-owners. Findings with regard to the two exclusion restriction variables used showed only one variable with a strong, yet inverse relationship with full-ownership of the farmland; namely, when the main occupation of the farm operator is farming. ${ }^{9}$

Results in Table 2 concerning debt servicing capacity $(D S C)$ based on the LRETE model show a statistically significant positive association between $D S C$ (in log form) and when the farm operator has a college education, and when the farm uses the internet in the farm business in addition to having crop insurance coverage, when it specializes in cash grains or dairy production, and when it is fully owned. Among all of these covariates, and based on an estimated $\hat{\delta}$ of 1.26 , full-ownership of farmland is shown with the largest positive impact, on average, on $\log (D S C){ }^{10}$ This finding of a significant and positive association between full-ownership of the farm and farmer's debt repayment capacity is in accordance with a reporting by Harris et al. (2009) that farmers with no accumulated debt by the end of a production year were more likely to be full owners than farmers who owed debt. This finding is not surprising considering the fact that a full-ownership of the farm, in contrast to a part-ownership or a full-tenant tenure arrangement, tends to be associated with households who are generally older and with higher education, and who tend to have higher average earned incomes from off-farm businesses and from off-farm wages and/or salaries in addition to higher shares, relative to average total household incomes, from these income sources (see Ahearn, Perry, \& El-Osta 1993; Mishra et al. 2002; D’Antoni, Mishra, \& Chintawar 2009).

The potential for higher incomes and increases in innovative abilities due to higher levels of education (see Nelson $\&$ Phelps 1966; Becker 1975; Huffman 1980 and 1981; El-Osta \& Morehart 1999; Mishra et al. 2002; Riddell 2007) may provide explanation for the positive impact of a college education by the farm operator on the farm household's ability to service its debt. The finding of a significant positive impact of college education on debt servicing capacity concurs broadly with the regression result by Reichert \& Posey (2011) that showed an inverse relationship between college education of the farm operator and the likelihood of default by the farm business.

With regard to the positive impact of Internet use on debt repayment capacity, the finding concurs with the result by Khanal \& Mishra 2013 which pointed to the positive impact of Internet access on the financial performance of small farms, those with annual sales of less than $\$ 250,000$ that comprise nearly 90 percent of all farms in the U.S. (see Hope \& Banker 2010). A study by Gloy \& Akridge (2000), however, suggested that the Internet utilization is more likely with larger farms operating under a multifaceted business and sophisticated farm management and with younger more educated farm operators. By the same token, the positive association found between the capacity to repay debt and when the farm participates in crop insurance coverage, which allows for risk reduction (see Mishra \& El-Osta, 2002), is consistent with the notion that such coverage improves the financial position of the farm operation. A study by Pflueger \& Barry (1986) found that crop insurance and its attendant positive response by lenders improved farms' survival and liquidity position.

In terms of the nature of association between specific farm types and debt repayment capacity, findings indicate that both cash grain crop and dairy farms, which are undergoing structural change towards larger and more profitable

\footnotetext{
9 An underidentification test [i.e., Kleibergen-Paap rank Lagrange Multiplier (LM) statistic] of whether a close variant of the specified model with identical set of explanatory variables is identified was performed using Stata's ivreg2 module. This test, which is tailored to discern whether the excluded instruments are relevant (i.e., correlated with the full-ownership variable) resulted in a value of $\mathrm{LM}=26.84$ ( $p=0.000$ ). Accordingly, the null hypothesis that the model was underidentified was strongly rejected.

${ }^{10}$ Since this coefficient can be interpreted as the average treatment effect, transforming this coefficient to allow for interpretation of its impact on the level of $D S C$ rather than on the $\log (D S C)$ show that the average debt repayment capacity for farm households who are full-owners of their farmland is $100\left(e^{1.2626}-1\right)=253.24 \%$ higher than the average debt repayment capacity for farm households who are either part-owners of their farmland or who are full-renters.
} 
operations resulting from scale economies (see Mosheim \& Lovell 2006; MacDonald et al. 2007; MacDonald, \& McBride 2009; MacDonald, Korb, \& Hoppe 2013), and based on positive and significant estimated coefficients, appear to be well positioned in terms of their ability to repay debt. This finding is in line with what is expected due to the capital-intensive nature of dairy operations and the requirement for capital, which is higher than all other farm types (Harris et al. 2008).

A negative association is found, as would be expected, between a farm household's debt repayment capacity and an increase in farm's financial inefficiency as measured by its higher operating expenses, when the farm receives most of its income from government payments, and when the farm has annual farm sales of $\$ 250,000$ or less. Regression results indicate a decrease in debt repayment capacity of 0.10 percent as a result of a 1 percent increase in operating expense. Similarly, an increase of 1 percent in the indicator reflecting the intensity of utilization of farm programs results in a reduction of 0.34 percent in the debt repayment capacity of farm households. The negative correlation between debt repayment and when the farms of farm households are small in size (with $\$ 250,000$ or less in farm sales) is explained by their significantly lower average household income than their counterparts with larger farm sizes. As was noted by Ahearn (2012), these larger-sized farms with farm sales of $\$ 250,000$ or more, which accounted for about 10 percent of all family farms and about 89 percent of farm production in 2010 while receiving less in off-farm income and significantly more from farming activity, had average household income in 2010 of more than twice the level of smaller farm households, at about $\$ 185,000$ in 2010 . A study by Gale (1994) provides a possible explanation for the larger income by larger-sized farms by noting their tendency to be less resource-constrained, which allows them to be in a better financial position to invest in cutting-edge technologies.

Findings in Table 2 of a negative and statistically significant coefficient of the 'Unemployment rate' variable, which indicates an adverse impact on farm households' debt repayment capacity, is in line with Briggeman's study (2011), which explained this impact by the increased reliance by farm households on off-farm employment to secure the main portion of their total income. The magnitude of the estimated coefficient indicates that a 1 percent rise in the county's unemployment rate, with all other factors being held constant, is associated with a decrease in the farm operator household's capacity to service its debt by $3.2 \%$.

To attend to the potential effect of the economic recession of 2008 and beyond on the debt repayment capacity of farm households, year dummy variables for the 2008-2013 time period were included in the estimation of the regression models. Findings show a statically negative correlation between debt repayment capacity and one of the six year-based binary indicator variables. In fact, with the estimated coefficient in the year 2008 being at -0.0929 which was the largest in absolute value of all of the other estimated coefficients of the year dummy variables, the predicted debt repayment capacity in the year when the economic recession had occurred, relative to the years 2004-2007, was reduced, holding all else constant, by $8.87 \%$ (i.e., by $100 *\left[\mathrm{e}^{-0.0929}-1\right]$ ). This is consistent with findings by Katchova, (2010) who noted that the economic recession of 2008 was associated with higher likelihood of farmers experiencing profitability, efficiency, and debt repayment issues. These findings are not surprising as the years 2004 and 2005, the years included in the base category in the analysis were among the years with the strongest financial efficiency and record farm income (see Covey et al. 2006; Briggeman 2010). Findings of positive and statistically significant coefficients of the years 2012 and 2013 are, in general, in accordance with the reporting by Patrick, Kuhns, \& Borchers (2016) of a surge from 2009 to 2013 in the farm sector's income and wealth due to increasing commodity revenues combined with smaller increases in farm expenses.

Unlike the results in Table 2 which are based on the modeling of the conditional mean of the $\log (D R C)$, Table 3 presents the results of estimating the conditional quantiles of this variable based on the quantile regression model as shown in (5), thus providing an account of all of its conditional distribution. Concern with regard to the potential endogeneity of the farmland ownership decision in the regression model was investigated by first fitting a probit regression model using the same exclusion restriction variables used in LRETE model (see Table 1), and in turn, by generating the generalized residuals as described in $(6)^{11}$. The second step involved re-estimating the quantile regression model in (5) at selected quantile levels with the vector of generalized residuals $\hat{\lambda}$ being included as an additional explanatory variable. The exogeneity of the dummy variable depicting full-ownership of the farmland by the married farm couple is rejected for the model at all of the reported quantiles based on the finding of a statistically significant ( $p$-value $=0.000)$ coefficient of $\hat{\lambda}$ (see Smith \& Blundell 1986; Rivers \& Voung 1988). Based on its low Pseudo $R^{2}$ of 0.030 , the regression model of the log of the debt repayment capacity of the farm household at the $90^{\text {th }}$ quantile, in comparison to the other models at the $10^{\text {th }}, 25^{\text {th }}, 50^{\text {th }}$, and $75^{\text {th }}$ quantiles, had the least explanatory power.

Concentrating on the $50^{\text {th }}$ quantile, findings based on the estimated coefficients in Table 3 show a positive and

11 While the results of the probit regression model representing full-ownership of farmland are not shown for brevity, they nevertheless could be obtained from the author upon request. 
statistically significant impact on the $\log (D R C)$ when the age of the operator is 35 years or younger and when the operator is college-educated. A similar positive and statistically significant impact was found when the Internet was used in the farm business or when there was a crop insurance coverage. With regard to the treatment effect variable depicting full-ownership of the farmland, its positive and statistically significant coefficient of 3.48 indicates a stronger increasing impact on $\log (D R C)$ than what was indicated by the LRETE model. Variables with an adverse impact on log $(D R C)$ at the $50^{\text {th }}$ quantile were those indicating a smaller size of farming operation with annual farm sales of less than $\$ 250,000$, and with those indicating an increase in both production inefficiency and on reliance on farm programs; this in addition to the location of the farm being in a metro area. Results further indicate that an increase in the unemployment rate by $1 \%$ based on the conditional-median regression tends to decrease the debt repayment capacity by $2.3 \%$. In 2008, the year when the financial crisis had occurred, and in the years 2010 and 2012, debt repayment capacity was lower than pre-2008 years by $17 \%$ (i.e., by $100 *\left[\mathrm{e}^{-0.0227}-1\right]$ ), and by $12 \%$ and $7 \%$, respectively.

Figure 3 shows the estimated coefficients of the quantile regression models of $\log (D S C)$ plotted against selected percentiles (i.e., between $10^{\text {th }}$ and $90^{\text {th }}$ ) of the distribution of the dependent variable along with the corresponding $95 \%$ confidence intervals computed based on bootstrap standard errors. The charts demonstrate the benefit of using quantile regression as it shows tremendous variation in the potential impact of the variables considered in the analysis on the debt repayment capacity of farm households across the various quantiles. For example, farm operators who are 35 years or younger tend to have their biggest impact on servicing debt, just like in the case of cash grain farmers and farmers who fully own their farmland, if they are located between the 0.1 and the 0.9 quantiles, and especially at the 0.5 quantile . Similarly, college-educated farmers and farmers whose farms are in a metro area have significantly higher ability to service farm household debt at the 0.9 quantile. Figure 3 demonstrates, as evident at all selected quantiles, the negative correlation between the debt repayment capacity of the farm household and when the size of the farming operation is small, particularly when annual farm sales are less than $\$ 50,000$. The adverse impact of unemployment and of the 2008 recession on debt repayment capacity of farm households were most severe at the 0.10 quantile.

Table 3. Quantile $(Q)$ Regression Estimates of Factors Affecting the Log of Debt Servicing Capacity of Farm Households, 2004-2013 ${ }^{1}$

\begin{tabular}{|c|c|c|c|c|c|}
\hline Variables & $\hat{\beta}_{0.10}$ & $\hat{\beta}_{0.25}$ & $\hat{\beta}_{0.5}$ & $\hat{\beta}_{0.75}$ & $\hat{\beta}_{0.90}$ \\
\hline \multirow[t]{2}{*}{ Intercept } & $3.6006^{* * *}$ & $4.1838^{* * *}$ & $4.9260^{* * *}$ & $5.8757^{* * *}$ & $6.9752^{* * *}$ \\
\hline & $(0.2541)$ & $(0.1497)$ & $(0.1108)$ & $(0.1009)$ & $(0.1503)$ \\
\hline \multirow[t]{2}{*}{ Age: $<=35$ years } & -0.0635 & $0.3113^{* * *}$ & $0.4201^{* * *}$ & $0.3057^{* * *}$ & 0.1028 \\
\hline & $(0.1772)$ & $(0.1016$ & $(0.0581)$ & $(0.0535)$ & $(0.0733)$ \\
\hline \multirow[t]{2}{*}{ College } & $0.3563^{* * *}$ & $0.3942^{* * *}$ & $0.3685^{* * *}$ & $0.3409^{* * *}$ & $\left(0.3789^{* * * * *}\right.$ \\
\hline & $(0.0569)$ & $(0.0315)$ & $(0.0228)$ & $(0.0204)$ & $(0.0320)$ \\
\hline \multirow[t]{2}{*}{ Sales: less than $\$ 50,000$} & $-2.3970^{* * *}$ & $-2.5913^{* * *}$ & $-2.6811^{* * *}$ & $-2.4407^{* * *}$ & $-2.2000^{* * * *}$ \\
\hline & $(0.2384)$ & $(0.1362)$ & $(0.1063)$ & $(0.0961)$ & $(0.1420)$ \\
\hline \multirow[t]{2}{*}{ Sales: $\$ 50,000-\$ 250,000$} & $-1.1490^{* * *}$ & $-1.2072^{* * *}$ & $-1.3209^{* * *}$ & $-1.3092^{* * *}$ & $-1.3927^{* * * *}$ \\
\hline & $(0.079)$ & $(0.0440)$ & $(0.0340)$ & $(0.0325)$ & $(0.0470)$ \\
\hline \multirow[t]{2}{*}{ Internet usage by farm business } & $0.4228^{* * * *}$ & $0.3900^{* * * *}$ & $0.3539^{* * * *}$ & $0.2803^{* * *}$ & $0.2068^{* * *}$ \\
\hline & $(0.0457)$ & $(0.0254)$ & $(0.0190)$ & $(0.0176)$ & $(0.0262)$ \\
\hline \multirow[t]{2}{*}{ Crop insurance coverage } & $0.8510^{* * *}$ & $0.7637^{* * *}$ & $0.7388^{* * *}$ & $0.5604^{* * *}$ & $0.3106^{* * *}$ \\
\hline & $(0.1393)$ & $(0.0781)$ & $(0.0586)$ & $(0.0530)$ & $(0.0776)$ \\
\hline \multirow[t]{2}{*}{ Log (operating expense ratio) } & $-0.1386^{* * * *}$ & $-0.1654^{* * *}$ & $-0.1357^{* * * *}$ & $-0.0611^{* * * *}$ & $-0.0372^{* *}$ \\
\hline & $(0.0327)$ & $(0.0202)$ & $(0.0178)$ & $(0.0136)$ & $(0.0155)$ \\
\hline \multirow[t]{2}{*}{ Log (intensity of farm payments) } & $-0.5962^{* *}$ & $-0.8362^{* * *}$ & $-0.9697^{* * *}$ & $-0.7432^{* * *}$ & $-0.3942^{* * *}$ \\
\hline & $(0.2270)$ & $(0.1253)$ & $(0.0924)$ & $(0.0871)$ & $(0.1310)$ \\
\hline \multirow[t]{2}{*}{ Cash grains } & $0.2406^{* *}$ & $0.4019^{* * *}$ & $0.4761^{* * *}$ & $0.3523^{* * *}$ & $0.1600^{* * *}$ \\
\hline & $(0.1005)$ & $(0.0596)$ & $(0.0421)$ & $(0.0396)$ & $(0.0560)$ \\
\hline \multirow[t]{2}{*}{ Dairy } & $0.3805^{* * *}$ & $0.4058^{* * *}$ & $0.4163^{* * *}$ & $0.2444^{* * *}$ & 0.0697 \\
\hline & $(0.1434)$ & $(0.0708)$ & $(0.0503)$ & $(0.0542)$ & $(0.0788)$ \\
\hline
\end{tabular}




\begin{tabular}{|c|c|c|c|c|c|}
\hline Metro & $-0.0728^{*}$ & $-0.0504^{*}$ & $-0.0403^{* *}$ & -0.0104 & $0.0813^{* * *}$ \\
\hline & $(0.0444)$ & $(0.0277)$ & $(0.0199)$ & $(0.0199)$ & $(0.0275)$ \\
\hline \multirow[t]{2}{*}{ Precipitation } & 0.0005 & $0.0016^{*}$ & $0.0014^{* *}$ & 0.0003 & $-0.0016^{*}$ \\
\hline & $(0.0015)$ & $(0.0008)$ & $(0.0006)$ & $(0.0006)$ & $(0.0008)$ \\
\hline \multirow[t]{2}{*}{ Unemployment rate } & $-0.0323^{* * * *}$ & $-0.0259^{* * *}$ & $-0.0227^{* * * *}$ & $-0.0128^{* * * *}$ & -0.0059 \\
\hline & $(0.0079)$ & $(0.0047)$ & $(0.0036)$ & $(0.0035)$ & $(0.0051)$ \\
\hline \multirow[t]{2}{*}{ Year: 2008 (financial crisis) } & $-0.2179^{* * * *}$ & $-0.0796^{*}$ & $-0.1860^{* * * *}$ & $-0.0904^{* * *}$ & $-0.0952^{* *}$ \\
\hline & $(0.0759)$ & $(0.0428)$ & $(0.0387)$ & $(0.0276)$ & $(0.0467)$ \\
\hline \multirow[t]{2}{*}{ Year: 2009} & -0.0792 & 0.0331 & -0.0464 & $-0.0824^{* * *}$ & -0.0752 \\
\hline & $(0.0779)$ & $(0.0463)$ & $(0.0360)$ & $(0.0307)$ & $(0.0508)$ \\
\hline \multirow[t]{2}{*}{ Year: 2010} & 0.0160 & 0.0021 & $-0.1281^{* * *}$ & $-0.1317^{* * *}$ & $-0.1096^{* *}$ \\
\hline & $(0.0807)$ & $(0.0471)$ & $(0.0354)$ & $(0.0369)$ & $(0.0510)$ \\
\hline \multirow[t]{2}{*}{ Year: 2011} & 0.0284 & 0.0775 & -0.0261 & -0.0151 & -0.0085 \\
\hline & $(0.0633)$ & $(0.0476)$ & $(0.0295)$ & $(0.0300)$ & $(0.0431)$ \\
\hline \multirow[t]{2}{*}{ Year: 2012} & 0.0644 & $0.0518^{*}$ & $-0.0689^{* * *}$ & $-0.0641^{* * * *}$ & -0.0131 \\
\hline & $(0.0677)$ & $(0.0376)$ & $(0.0263)$ & $(0.0263)$ & $(0.0423)$ \\
\hline \multirow[t]{2}{*}{ Year: 2013} & 0.0976 & $0.1101^{* * * *}$ & 0.0280 & 0.0357 & 0.0319 \\
\hline & $(0.0656)$ & $(0.0359)$ & $(0.0241)$ & $(0.0262)$ & $(0.0448)$ \\
\hline \multirow[t]{2}{*}{ Full owner } & $2.8456^{* * *}$ & $3.3323^{* * *}$ & $3.4815^{* * *}$ & $2.5510^{* * *}$ & $1.4098^{* * *}$ \\
\hline & $(0.6588)$ & $(0.3800)$ & $(0.2908)$ & $(0.2601)$ & $(0.3902)$ \\
\hline \multirow[t]{2}{*}{ Generalized residual $(\lambda)$} & $-1.6157^{* * *}$ & $-1.9308^{* * *}$ & $-2.0680^{* * *}$ & $-1.5132^{* * *}$ & $-0.8236^{* * *}$ \\
\hline & $(0.3875)$ & $(0.2220)$ & $(0.1705)$ & $(0.1539)$ & $(0.2310)$ \\
\hline Pseudo $R^{2}$ & 0.298 & 0.333 & 0.288 & 0.150 & 0.030 \\
\hline
\end{tabular}

Note: ${ }^{*} p<0.10 .{ }^{* *} p<0.05 .{ }^{* * *} p<0.01$. Standard errors computed based on 1,000 replicate samples are in parentheses. ${ }^{1}$ Pseudo $R^{2}=1-\frac{V_{\tau}^{f}}{V_{\tau}^{r}}$, where $V_{\tau}^{f}$ is the sum of the weighted distances for the full quantile regression model (see equation (5)), and $V_{\tau}^{r}$ is the sum of the weighted distances for the restricted model that includes only the intercept (for more detail, see Hao \& Naiman, 2007; pp. 51-52). 

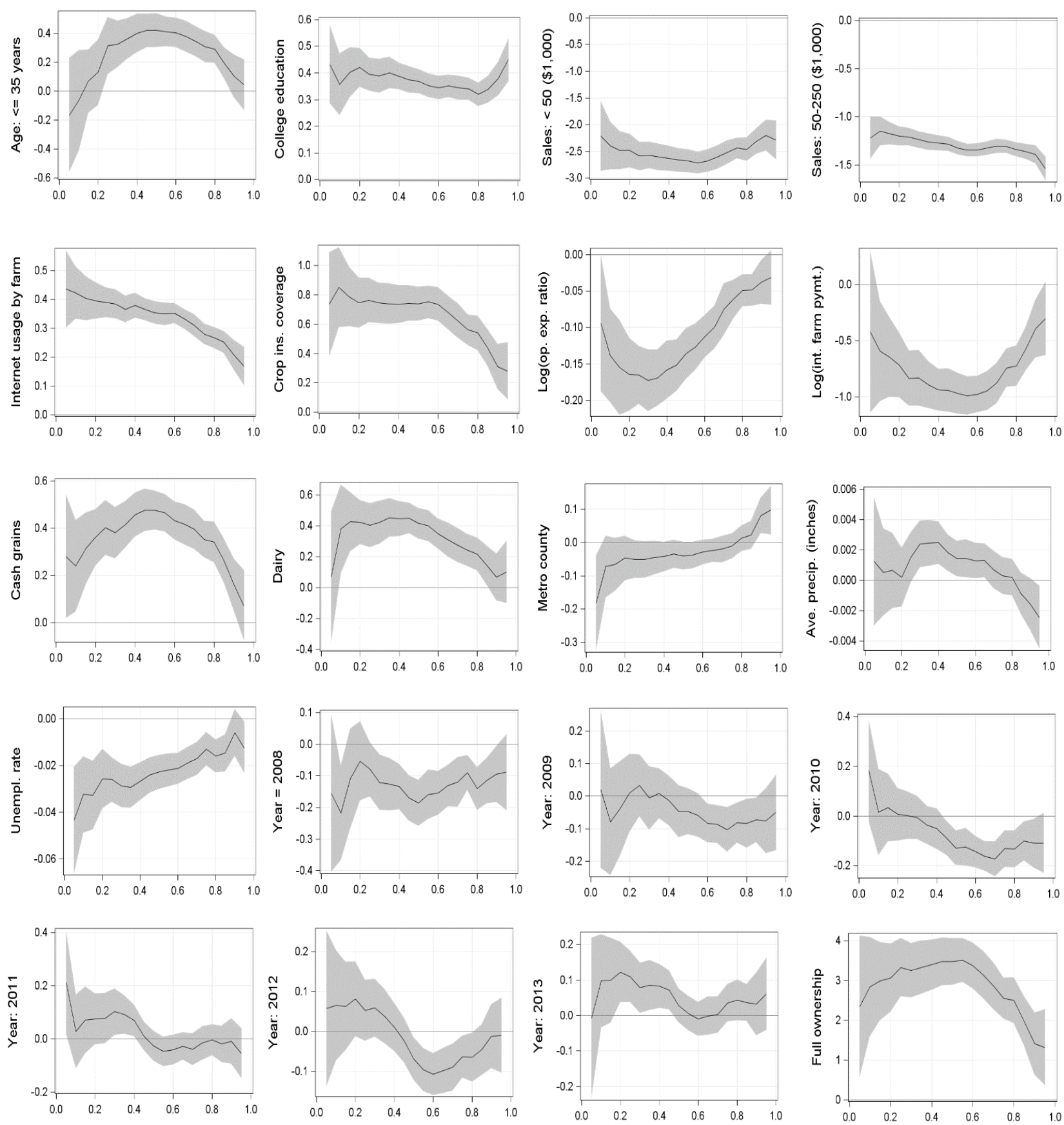

Figure 3. Quantile Regression Coefficient Estimates and Bootstrap 95\% Confidence Envelopes for Farm Household Debt Servicing Capacity Model at Various Quantiles, 2004-2013

\section{Conclusions}

This paper investigated the potential impact of full ownership of farmland on the debt repayment capacity of married farm couples using linear and quantile regression estimation methods in conjunction with data from the 2004-2013 Agricultural Resource Management Survey. By utilizing, respectively, the endogenous treatment effect regression technique and the control function approach in the linear and the quantile regressions to attend to the endogeneity concerns of full-ownership of farmland, findings indicated a strong and statistically significant positive impact of full-farm ownership on the ability of farm households to repay their debt. Other factors that were found with a strong and positive impact on debt repayment capacity were those related to the age of the farm operator, particularly between the $10^{\text {th }}$ and the $90^{\text {th }}$ quantiles of the distribution of debt repayment, and to the education of the operator; especially the college-educated. Having insurance coverage and using the internet in the farm business were shown, regardless of the 
regression technique used, to be positively associated with the ability of the farm households to repay their debt. The financial crisis of 2008 along with increases in unemployment rates had strong adverse impact on debt repayment capacity with the strongest impact being observed at the $10^{\text {th }}$ quantile.

The adverse roles of the financial crisis and of increases in the unemployment rates on the debt repayment capacity of the farm households become more apparent when viewed in the context of the increased reliance of these farm households on off-farm work with its attendant dependence on a strong economy in general, and on vibrant off-farm labor market conditions in particular. A study by Brown \& Weber (2013) provides indirect evidence of the positive impact of lower unemployment rates on debt servicing capacity as it shows that when farm operators and their spouses work off farm, and consistent with the notion that farming requires substantial management skills, they are most likely to hold a management or professional occupation that tends to earn higher wages. The contributing role off farm income has in managing risk through diversification of income has been noted in the literature (Mishra \& Goodwin, 1997; Barrett, Reardon, \& Webb. 2001). The influence of off-farm income with its importance to full-owners of farmland (see Ahearn, Perry, \& El-Osta 1993), in turn, helps in shedding light on the potential positive linkage between off-farm work where the likelihood of such work increases due to strong economic and labor market conditions, and the ability of farm households to service their debt. Considering the finding of a strong correlation between full-ownership of farmland and debt serving capacity, and in light of the increased dependence by farmland owners on off-farm income suggests Federal policies aimed at increasing off-farm job opportunities could help in mitigating the likelihood of financial stress among land-owning farm households. With a value of farmland in 2013 of about $\$ 0.53$ trillion by land-owning married farm couples based on data from the ARMS, policies that foster a stable and sustainable local economic conditions and a strong agricultural economy should have a positive impact on both, the financial wellbeing of these farm households and on their local communities through higher local income and property taxes.

\section{Acknowledgements}

The author is grateful to Ryan Williams (Economic Research Service) for his expertise and for his kind support in providing the climate data needed in this research.

\section{References}

(2011). The importance of off-farm income to serving farm debt. Federal Reserve Bank of Kansas City. Economic Review, (First Quarter), 83-102.

(1998). Recent advances in quantile regression models: A practical guideline for empirical research. Journal of Human Resources, 33(1), 88-126. http://dx.doi.org/10.2307/146316

(1981). Black-white human capital differences: Impact on agricultural productivity in the U.S. south. American Economic Review, 71(1), 94-107.

Adkins, L. C, \& Carter Hill, R. (2004). Bootstrap inferences in heteroscedastic sample selection models, a Monte Carlo investigation. Paper presented at the $74^{\text {th }}$ Southern Economic Association meetings, New Orleans, LA, November 21-23.

Aguiar, M., \& Hurst, E. (2013). Deconstructing life cycle expenditure. Journal of Political Economy, 121(3), 437-492. http://dx.doi.org/10.1086/670740

Ahearn, M. C. (2012). Financial position of farm operator households. Paper presented at USDA Agricultural Outlook Forum, February 23.

Ahearn, M. C., Perry, J. E., \& El-Osta, H. S. (1993). The economic well-Being of farm operator households, 1988-90. AER-666, U.S. Department of Agriculture, Washington, DC.

Altonji, J. G., \& Doraszelski, U. (2001). The role of permanent income and demographics in black/white differences in wealth. Working paper No. 8473, National Bureau of Economic Research, Cambridge, MA.

Barrett, C. B., Reardon, T., \& Webb, P. (2001). Nonfarm income diversification and household livelihood strategies in rural Africa, concepts, dynamics and policy implications. Food Policy, 26(4), 315-331. http://dx.doi.org/10.1016/S0306-9192(01)00014-8

Becker, G. S. (1975). Human capital: A theoretical and empirical analysis with special reference to education. New York: National Bureau of Economic Research and Columbia University Press.

Borchers, A., \& Kuethe,T. (2012). Farm Real Estate Values and Cash Rent. In C. Osteen, J. Gottlieb, \& U. Vasavada (Eds.), Agricultural resources \& environmental indicators, 7-9.

Box, G. E. P., \& Cox, D. R. (1964). An analysis of transformations. Journal of the Royal Statistical Society, Series B 26(2), 211-252.

Briggeman, B. C. (2010). Debt, income and farm financial stress. The Main Street Economist, 6, 1-5. 
Briggeman, B. C., Towe, C. \& Morehart, M. (2009). Credit constraints: Their existence, determinants, and implications for U.S. farm and nonfarm sole proprietorships. American Journal of Agricultural Economics, 91(1), 275-289. http://dx.doi.org/10.1111/j.1467-8276.2008.01173.x

Brown, J. P., \& Weber, J. G. (2013). The off-farm occupations of U.S. farm operators and their spouses. EIB 117. U.S. Department of Agriculture, Washington, DC.

Buchinsky, M. (1994). Changes in the U.S. wage structure 1963-1987: Application of quantile regression. Econometrica, 62(2), 405-458. http://dx.doi.org/10.2307/2951618

Burbidge, J. B., Magee, L., \& Robb, A. L. (1988). Alternative transformations to handle extreme value of the dependent variable. Journal of the American Statistical Association, 83(401), 123-127. http://dx.doi.org/10.1080/01621459.1988.10478575

Chen, M. Y., Lin, F. L., \& Chang, C. K. (2009). Relations between health care Expenditure and income: An application of local quantile regressions. Applied Economics Letters, 16(2), $177-181$. http://dx.doi.org/10.1080/13504850601018114

Cochrane, W. W. (1993). The Development of American Agriculture: A Historical Analysis. $2^{\text {nd }}$ edition. Minneapolis: University of Minnesota Press.

Covey, T., Green, R., Johnson, J., Jones, C., Morehart, M., Strickland, R., Traub, L., Brown, D., Reeder, R., McGath, C., Williams. B., Erickson, K., Mishra, A., Vogel, S., \& Bagi, F. (2006). Agricultural Income and Finance Outlook AIS-84. U.S. Department of Agriculture, Washington, DC.

Covey, T., Johnson, J., Morehart, M., Ryan, J., McGath, C., Traub, L., Green, R., McBride, W., Hopkins, J., Strickland, R., Mishra, A., Durst, R., Williams, R., \& Erickson, K. (2004). Agricultural Income and Finance Outlook. AIS-82. U.S. Department of Agriculture, Washington, D. C.

D’ Antoni, J., Mishra, A., \& Chintawar, S. (2009). Predicting financial stress in young and beginning farmers in the United States. Paper presented at the Southern Agricultural Economics Association annual meeting, Atlanta, Georgia, January 31 - February 3.

Deaton, A. S. (1989). Rice Prices and Income Distribution in Thailand: a Non-Parametric Analysis. The Economic Journal, 99(395), 1-37. http://dx.doi.org/10.2307/2234068

Dubman, R. W. (2000). Variance Estimation with USDA's Farm Costs and Returns Surveys and Agricultural Resource Management Study Surveys. ERS Staff Paper, AGES 00-01. U.S. Department of Agriculture, Washington, DC.

Economic Research Service (ERS). 2015. ARMS Data. U.S. Department of Agriculture, Washington, DC. http://www.ers.usda.gov/data-products/arms-farm-financial-and-crop-production-practices/arms-data.aspx

Efron, B., \& Tibshirani, R. J. (1994). An Introduction to the Bootstrap. New York: Chapman \& Hall.

El-Osta, H. S., \& Morehart, M. J. (1999). Technology adoption decisions in dairy production and the role of herd expansion. Agricultural and Resource Economics Review, 28(1), 84-95.

Farm Financial Standards Council (FFSC). (2011). Financial Guidelines for Agricultural Producers, Farm Financial Standards Council, Menomonee Falls, WI. http://www.ffsc.org/index.php/2012/06/01/farm-financial-guidelines-and-ratios/

Featherstone, A. M., Roessler, L. M., \& Barry, P. J. (2006). Determining the probability of default and risk-rating class for loans in the Seventh Farm Credit District portfolio. Applied Economic Perspectives and Policy, 28(1), 4-23. http://dx.doi.org/10.1111/j.1467-9353.2006.00270.x

Gale, H. F. (1994). Longitudinal analysis of farm size over the farmer's life cycle. Review of agricultural economics, 16(1), 113-123. http://dx.doi.org/10.2307/1349526

Gilbert, J., \& Harris, C. K. (1984). Changes in type, tenure, and concentration of U.S. farmland owners. Research in Rural Sociology and Development, 1, 135-160.

Gloy B. A., \& Akridge, J. T. (2000). Computer and Internet adoption on large U.S. farms. International Food and Agribusiness Management Review, 3(3), 323-338. http://dx.doi.org/10.1016/S1096-7508(01)00051-9

Gloy, B. (2015). Digging into Farm Debt. http://ageconomists.com/2015/07/07/digging-into-farm-debt/

Gould, B. W., \& Saupe, W. E. (1989). Off-farm labor market entry and exit. American Journal of Agricultural Economics, 71(4), 960-969. http://dx.doi.org/10.2307/1242672

Gourieroux, C. (1987). Generalized residuals. Journal of Econometrics, 34(1-2), 5-32. http://dx.doi.org/10.1016/0304-4076(87)90065-0 
Hao, L. D., \& Naiman, Q. (2007). Quantile regression. Sage Publications, Inc., Thousand Oaks, CA. http://dx.doi.org/10.4135/9781412985550

Harris, J. M., Erickson, K., Dillard, J., Morehart, M., Strickland, R., Gibbs, R., Ahearn, M., Covey, T., Bagi, F., Brown, D., McGath, C., Vogel, S., Williams, B., \& Johnson, J. (2008). Agricultural income and finance outlook AIS-86. U.S. Department of Agriculture, Washington, DC.

Harris, Johnson, M. J., Dillard, J., Williams, R., \& Dubman, R. (2009). The debt finance land scape for U.S. farming and farm businesses. AIS-87. U.S. Department of Agriculture, Washington, DC.

Hertz, H., Kusmin, L., Marré, A., \& Parker T. (2014). Rural Employment Trends in Recession and Recovery. ERR-172. U.S. Department of Agriculture, Washington, DC.

Hoppe, R. A. (2014). Structure and Finances of U.S. Farms: Family Farm Report, 2014. Edition, EIB-132, U.S. Department of Agriculture, Washington, DC.

Huffman, W. E. (1980). Farm and off-farm work decisions: The role of human capital. Review of Economics and Statistics, 62(1), 14-23. http://dx.doi.org/10.2307/1924268

Hunter, B. (2006). Further explorations of the role of crime in indigenous employment status. Australian Journal of Labour Economics, 9(2), 217-237.

Katchova, A. (2010). Structural Changes in U.S. Agriculture: Financial Performance of Farms in Transition. Paper prepared for presentation at the $114^{\text {th }}$ EAAE Seminar 'Structural Change in Agriculture', Berlin, Germany, April $15-16$.

Khanal, A. R., \& Mishra, A. K. (2013). Assessing the impact of Internet access on household income and financial performance of small farms. Paper presented at the Southern Agricultural Economics Association Annual Meeting, Orlando, Florida, February 2-5.

Kmenta, J. (1986). Elements of Econometrics. Macmillan Publishing Company: New York.

Koenker, R., \& Bassett, G., Jr. (1978). Regression quantiles. Econometrica, 46(1), 33-50. http://dx.doi.org/10.2307/1913643

Kott, P. S. (1997). Using the Delete-a-Group Jackknife Variance Estimator in NASS Surveys. U.S. Department of Agriculture, National Agricultural Statistics Service.

Kropp, J. D., \& Katchova, A. L. (2011). The effects of direct payments on liquidity and repayment capacity of beginning farmers. Agricultural Finance Review, 71(3), 347-365. http://dx.doi.org/10.1108/00021461111177611

Lee, S. (2007). Endogeneity in quantile regression models: A control function approach. Journal of Econometrics, 141(2), 1131-1158. http://dx.doi.org/10.1016/j.jeconom.2007.01.014

MacDonald, J. M., O’ Donoghue, E. J., McBride, W., Nehring, R. F., Sandretto, C. L., \& Mosheim, R. (2007). Profits, Costs, and the Changing Structure of Dairy Farming. ERR-47. U.S. Department of Agriculture, Washington, D.C. http://dx.doi.org/10.2139/ssrn.1084458

MacDonald, J., \& McBride, W. D. (2009). The Transformation of U.S. Livestock Agriculture: Scale, Efficiency and Risks. EIB-43. U.S. Department of Agriculture, Washington, DC.

MacDonald, J., Korb, P., \& Hoppe, R. (2013). Farm Size and the Organization of U.S. Crop Farming. ERR-152. U.S. Department of Agriculture, Washington, DC.

Maddala, G. S. (1983). Limited-Dependent and Qualitative Variables in Econometrics. Cambridge: Cambridge University Press. http://dx.doi.org/10.1017/CBO9780511810176

Miller, A., Boehlje, M., \& Dobbins, C. (2000). Can I repay ? Managing farm debt repayment capacity. Purdue Agricultural Economics Report (July). http://agribusiness.purdue.edu/files/resources/a-7-2000-miller-boehlje-dobbins.pdf

Mishra, A. K., \& El-Osta, H. S. (2002). Managing risk in Agriculture through hedging and crop insurance: What does a national survey reveal? Agricultural Finance Review, 62(2), 135-148. http://dx.doi.org/10.1108/00214930280001134

Mishra, A. K., El-Osta, H. S., Morehart, M. J., Johnson, J. D., \& Hopkins, J. W. (2002). Income, Wealth, and the Economic Well-Being of Farm Households. AER-812. U.S. Department of Agriculture, Washington, DC.

Mishra, A., \& Goodwin, B. K. (1997). Farm income variability and the supply of off-farm labor. American Journal of Agricultural Economics, 79(3), 880-887. http://dx.doi.org/10.2307/1244429

Mishra, A., Wilson, C., \& Williams, R. (2009). Factors affecting financial performance of new and beginning farmers. 
Agricultural Finance Review, 69(2), 160-179. http://dx.doi.org/10.1108/00021460910978661

Mosheim, R., \& Lovell, C. A. K. (2006). Economic efficiency, structure and scale economies in the U.S. dairy sector. Paper presented at the annual meetings of the American Agricultural Economics Association, Long Beach, CA, July 23-26.

Nelson, R. R., \& Phelps, E. S. (1966). Investment in humans, technological diffusion, and economic growth. American Economic Review, 56(1/2), 69-75.

Nickerson, C., Morehart, M., Kuethe, T., Beckman, J., Ifft, J., \& Williams, R. (2012). Trends in Farmland Values and Ownership. EIB-92. U.S. Department of Agriculture, Washington, DC.

Patrick, K, Kuhns, R., \& Borchers, A. (2016). Recent trends in U.S. farm income, wealth, and financial health. Choices 1st Quarter,31(1), 1-8.

Pflueger, B. W., \&, Barry P. J. (1986). Crop insurance and credit: A farm level simulation analysis. Agricultural Finance Review, 46(1), 1-14.

Reichert, A., \& Posey, R. (2011). Using financial ratios and lender relationship theory to assess farm credit worthiness. Accounting and Taxation, 3(1), 45-56.

Riddell, W. C. (2007). The impact of education on economic and social outcomes: An overview of recent advances in economics. In G. Picot, R. Saunders and A. Sweetman (Eds.), Fulfilling potential, creating success: perspectives on human capital development. Montreal and Kingston: McGill-Queen's University Press.

Rivers, D., \& Vuong, Q. H. (1988). Limited information estimators and exogeneity tests for simultaneous probit models. Journal of Econometrics, 39(3), 347-366. http://dx.doi.org/10.1016/0304-4076(88)90063-2

Ryan J. T. (1995). Utilization of debt repayment capacity by commercial farm operators. Paper presented at the American Agricultural Economics Association annual meeting, Indianapolis, Indiana.

Ryan, J. T., \& Morehart, M. (May 1992). Debt repayment capacity of commercial farm operators: How much debt can farmers afford? Agricultural Income and Finance: Situation and Outlook Report. AF0-45. U.S. Department of Agriculture, Washington, DC.

Smith, R. J., \& Blundell, R. W. (1986). An exogeneity test for a simultaneous equation tobit model with an application to labor supply. Econometrica, 54(3), 679-685. http://dx.doi.org/10.2307/1911314

Stam, J., D., Milkove, Koenig, S., Ryan, J., Covey, T., Hoppe, R., \& Sundell, P. (2003). Agricultural income and finance annual lender issue. Outlook Report AIS-80. U.S. Department of Agriculture, Washington, D.C.

Stam, J., Milkove D., Collender, R., Dodson, C., Duncan, M., Koenig, S., Covey, T., Ryan, J., Barnard, C., Westenbarger, D., \& Gajewski, G. (1998). Agricultural Income and Finance-Situation and Outlook. AIS-68. U.S. Department of Agriculture, Washington, DC.

StataCorp. (2013). Stata treatment effects reference manual. Stata: Release 13. Statistical Software (College Station, TX: StataCorp LP.

Terza, J. V., Basu, A., \& Rathouz, P. J. (2008). Two-stage residual inclusion estimation: Addressing endogeneity in health econometric modeling. Journal of Health Economics, 27(3), 531-543. http://dx.doi.org/10.1016/j.jhealeco.2007.09.009

Tokle, J. G., \& Huffman, W. E. (1991). Local economic conditions and wage labor decisions of farm and rural non-farm couples. American Journal of Agricultural Economics, 73(3), 652 -670. http://dx.doi.org/10.2307/1242818

Vella, F. (1992). Simple tests for sample selection bias in censored and discrete choice models. Journal of Applied Econometrics, 7(4), 413-421. http://dx.doi.org/10.1002/jae.3950070407

\section{$(\mathrm{cc}) \mathrm{BY}$}

This work is licensed under a Creative Commons Attribution 3.0 License. 